\title{
DO FOREIGN AID TRANSFERS DISTORT INCENTIVES AND HURT GROWTH? THEORY AND EVIDENCE FROM 75 AID-RECIPIENT COUNTRIES
}

\author{
GEORGE ECONOMIDES \\ SARANTIS KALYVITIS \\ APOSTOLIS PHILIPPOPOULOS
}

\begin{abstract}
CESIFO WORKING PAPER NO. 1156
CAtegory 5: Fiscal Policy, Macroeconomics and Growth MARCH 2004

Presented At CESifo-DelPhi CONFERENCE ON “Designing the NeW EU" NOVEMBER 2003

An electronic version of the paper may be downloaded

- from the SSRN website: $\quad$ www.SSRN.com

- from the CESifo website: www.CESifo.de
\end{abstract}




\title{
DO FOREIGN AID TRANSFERS DISTORT INCENTIVES AND HURT GROWTH? THEORY AND EVIDENCE FROM 75 AID-RECIPIENT COUNTRIES
}

\begin{abstract}
In this paper, foreign aid transfers can distort individual incentives, and hence hurt growth, by encouraging rent-seeking as opposed to productive activities. We construct a model of a small growing open economy that distinguishes two effects from foreign transfers: (i) a direct positive effect, as higher transfers allow the financing of infrastructure; (ii) an indirect negative effect, as higher transfers induce rent-seeking competition on the part of selfinterested individuals. In this framework, the growth impact of aid is examined jointly with the determination of rent-seeking behavior. We test the main predictions of the model for a cross-section of 75 aid-recipient countries between 1975 and 1995. There is evidence that aid has a direct positive effect on growth, which is however significantly mitigated by the adverse indirect effects of associated rent-seeking activities. This is especially the case in recipient countries with relatively large public sectors.
\end{abstract}

JEL classification: F35, D7, D9, H2.

Keywords: foreign aid, incentives, growth.

George Economides

Athens University of Economics and Business

76 Patission street

Athens 10434

Greece
Sarantis Kalyvitis

Athens University of Economics and Business

76 Patission street

Athens 10434

Greece

skalyvitis@aueb.gr

\author{
Apostolis Philippopoulos \\ Athens University of Economics and \\ Business \\ 76 Patission street \\ Athens 10434 \\ Greece \\ aphil@aueb.gr
}

We thank Konstantinos Angelopoulos for excellent research assistance and many helpful comments. We are grateful to Hyun Park and Vangelis Vassilatos for discussions and related joint work. We have also benefited from comments by Panos Hatzipanayotou, Thomas Moutos, Albrecht Ritschl and Elias Tzavalis, as well as seminar participants at the CESifoDelphi conference on "Designing the New EU" held at Munich in November 2003. Any errors are ours. 


\section{Introduction}

The effects of foreign aid on recipient countries' growth are, at best, ambiguous. In many cases, despite earlier optimistic expectations, aid has failed to boost growth. ${ }^{1}$ A prevalent explanation seems to be that foreign aid is often misused and misappropriated. For instance, it can foster corruption in recipient countries. ${ }^{2}$ In this paper, we revisit these issues by studying, both theoretically and econometrically, the joint determination of economic growth and appropriative (or rent-seeking) behavior when the driving force is foreign aid transfers. ${ }^{3}$ The emphasis is on individual incentives.

We model a small growing open economy in which domestic taxes and foreign transfers can co-finance public infrastructure. The latter is the engine of long-term growth, as in the model introduced by Barro (1990). We distinguish two effects of foreign transfers on the recipient country's growth rate: (i) A direct positive effect through the financing of public productive services. (ii) An indirect negative effect through the distortion of individuals' incentives; the focus here will be on appropriative, or rent-seeking, competition for a fraction of those transfers. Specifically, we show that under certain conditions (depending on the relation between the magnitude of foreign transfers and the size of the recipient country's public sector), the possibility of extraction from foreign transfers pushes self-interested individuals away from productive work to rent-seeking competition (modeled as a non-cooperative Nash game) in an attempt to appropriate extra resources for their own benefit. ${ }^{4}$ This is at the society's expense and

\footnotetext{
${ }^{1}$ See Drazen (2000, chapter 12.9) for a survey. Empirical studies on the growth impact of aid include Mosley et al. (1987), Boone (1996), World Bank (1998), Svensson (1999) and Easterly (2001). Moreira (2003) has surveyed the empirical evidence from cross-country regression studies and has found that, out of seventy-two regressions, the estimated effect is positive in forty regressions, non-significant in thirty-one and negative in one regression.

${ }^{2}$ See again Drazen (2000, chapter 12.9) for a survey. As Alesina and Weder (2002) point out, foreign aid fosters corruption by increasing the size of resources that interest groups fight over. Casual observations suggest that foreign transfers favor certain social and professional groups, or particular firms and industries. This can take place directly and indirectly. For instance, an indirect transfer mechanism is measures that increase the demand for a certain group's services.

${ }^{3}$ The term rent seeking will be used "in the broad sense as referring to the socially costly pursuit of income and wealth transfers" (Drazen, 2000, p. 335). Notice that we will use the terms "rent seeking", "appropriation" and "extraction" interchangeably.

${ }^{4}$ This is basically a common-pool problem. That is, there is a possibility of common access to a social resource and this, in turn, opens the door to anti-social behavior among self-interested individuals. Different papers differ in what the common-pool resource is. This is a rich and still growing literature (for a survey, see Drazen, 2000, chapter 10.7). Some recent papers, not included in Drazen, are: Svensson (2000), where (as in our paper) the common-pool resource is aid transfers; Leite and Weidmann (2002) and Grossman and Mendoza (2003), where the common-pool resource is natural resources; Mauro (2002) and Park et al. (2003) where the common-pool resource is government income.
} 
may counterbalance the manna-from-heaven direct effect that foreign aid is anticipated to have on economic growth. The larger the amount of aid and the size of the recipient country's public sector, the stronger are the rent-seeking activities.

We test these predictions by using data for a pooled cross-section of 75 aid-recipient countries between 1975 and 1995 for which proxies of rent-seeking behavior are available. Following most of the related literature, we use the Knack-Keefer $(1995,1997)$ indices as measures of rent-seeking behavior. Our econometric results indicate that, when economic growth and rent seeking are examined jointly with aid transfers, a rise in the latter exerts ceteris paribus a direct positive effect on economic growth. However, this effect is mitigated by an endogenous rise in rent-seeking activities triggered by the same rise in aid. Eventually, the net growth effect of aid is substantially smaller compared to the direct positive effect. Moreover, in accordance with the theory, there is evidence that the deleterious effect of aid upon incentives, and in turn growth, is stronger in recipient countries with relatively large public sectors. This evidence confirms the common belief that rent seeking from aid transfers takes place through government activities. Intuitively, corrupt government officials have some effective property rights over the aid transfers they are allocating, and this gets worse with the size of public sector. ${ }^{5}$

What is the related theoretical literature? The paper closest to ours is Svensson (2000). Svensson develops a game-theoretic model with rent seeking competition and shows how a cooperative solution, namely one without rent seeking, can be achieved if the game is repeated over time; foreign aid makes such a cooperative solution more difficult to sustain. Our work differs mainly because here we use a standard model of endogenous growth, in which public infrastructure is co-financed by domestic taxes and foreign transfers, where the latter redistribute from above-average to below-average income countries. As Chatterjee et al. (2003) point out, this is the idea behind most international transfer programs. We manage to get an analytic and testable solution that distinguishes the direct and indirect effects of aid upon individual incentives and macroeconomic outcomes.

On the empirical side, the existing econometric studies have so far focused on bivariate relations between aid and corruption (see e.g. Svensson, 2000, Alesina and Weder, 2002, Tavares, 2003), growth and aid (see e.g. the references in footnote 1 above) and growth and corruption (see e.g. Mauro, 1995, Knack and Keefer, 1995). Our paper bridges a gap between

\footnotetext{
${ }^{5}$ See Tanzi (2002) for the role of public sector in corruption.
} 
these empirical relations by examining the joint determination of rent seeking, growth and aid. To our knowledge, there has been no attempt so far to examine these connections in a unified framework.

Our findings may help to explain why past studies were frequently unsuccessful in establishing a substantial positive impact of aid on growth, as aid-induced rent-seeking activities were typically ignored. Our paper may also offer a potential resolution to the "micro-macro paradox" (Mosley, 1986), according to which aid is found to impact positively when it is evaluated at firms' investment level by means of cost-benefit project analysis, whereas this positive effect largely evaporates at the level of cross-country regressions.

The rest of the paper is organized as follows. Section 2 presents a theoretical model. Section 3 specifies the econometric model and describes the data. Section 4 presents the empirical results. Section 5 concludes and discusses policy implications.

\section{A theoretical model of growth, incentives and foreign transfers}

We will incorporate foreign transfers, and rent-seeking competition for a fraction of them, into a model of growth. We do so because we believe it is important to address the problems of incentives and aid in the context of economic growth. In particular, we will build on the model introduced by Barro (1990), in which public production services generate endogenous growth. We choose this model because it is well known and algebraically simple. ${ }^{6}$

We will first present the key features of the model and then turn to formal modeling.

\subsection{Informal description of the model}

The key features of the theoretical model are as follows: ${ }^{7}$ (a) The government uses domestic tax revenues and foreign transfers to finance public productive services. The latter provide a positive production externality to private firms. (b) Only a fraction of foreign transfers is actually used to finance public services. The rest can be extracted by self-interested individuals. Specifically, we

\footnotetext{
${ }^{6}$ See e.g. Barro and Sala-i-Martin (1995, chapter 4.4) for a detailed study of this model. There are numerous applications of this model. As is known, this is a variant of the linear $A K$ model at aggregate level.

7 As said above, a model close to ours is Svensson's (2000). However, here we use a general equilibrium model of growth rather than a partial equilibrium setup with exogenous output. A growth model with aid transfers close to ours is Chatterjee et al. (2003). That model produces interesting dynamics but it does not study incentives. Our model also borrows from Park et al. (2003). However, here agents extract from aid transfers.
} 
assume that households can extract from total foreign transfers to increase their own personal wealth. ${ }^{8}$ In doing so, they compete with other households. This rent-seeking competition will be modeled as a non-cooperative (Nash) game among self-interested individuals. (c) Extraction comes at a private cost. ${ }^{9}$ Specifically, it requires time and effort. Thus, each household chooses optimally (in addition to consumption and saving) the allocation of its time and effort to productive work and rent-seeking activities. ${ }^{10}$ (d) The fraction of foreign transfers appropriated by each individual is proportional to the effort and time that he, or she, allocates to rent-seeking competition relative to the total effort and time allocated to rent-seeking competition by all individuals. Then, the aggregate rent-seeking effort will deplete the flow of foreign transfers earmarked for the finance of public services. (e) The economy is small so that it takes the rest of the world as given. For simplicity, we assume that there is only one link with the rest of the world and this is via foreign transfers.

\subsection{Firms' behavior}

Firms are indexed by $j=1,2, \ldots, J$ and are modeled as in Barro and Sala-i-Martin (1995, chapter 4). Each firm $j$ maximizes profits, $\pi^{j}$ :

$\pi^{j}=(1-\theta) y^{j}-r k^{j}-w l^{j}$

where $0<\theta<1$ is a common proportional output tax rate; ${ }^{11} y^{j}, k^{j}$ and $l^{j}$ are respectively $j$ 's output, capital and labor; and $r$ and $w$ are the market interest rate and wage rate.

At the firm's level, the production function is:

$y^{j}=A\left(k^{j}\right)^{\alpha}\left(l^{j}\right)^{1-\alpha} G^{1-\alpha}$

where $G$ is aggregate public production services, and $A>0$ and $0<\alpha<1$ are parameters.

\footnotetext{
${ }^{8}$ We could assume that firms, like households, also extract for their personal benefit a fraction of foreign transfers. This is not important to our results because households are also firm-owners in this class of models. We could also assume that policymakers extract from aid transfers. Again this is not important; adding more types of self-interested individuals does not affect our main result.

${ }^{9}$ Extracting favors from the government, breaking the law, bribing, lobbying, etc, are costly activities.

${ }^{10}$ The idea is as in e.g. Baumol (1990), Murphy et al. (1991), Grossman and Kim (1996), Grossman (2000, 2002), Mauro (2002) and Grossman and Mendoza (2003), where individuals decide how to allocate their activities between "productive" ones (such as work, innovation and entrepreneurship) and "unproductive" ones (such as rent seeking and violating property rights).

${ }^{11}$ We could use taxes on households' income. The type of distorting taxation used is not important to our results.
} 
Each firm $j$ acts competitively taking prices $(r, w)$ and policy $(\theta, G)$ as given. This is a simple static problem whose first-order conditions for $k^{j}$ and $l^{j}$ are:

$$
\begin{aligned}
& r=(1-\theta) \alpha \frac{y^{j}}{k^{j}} \\
& w=(1-\theta)(1-\alpha) \frac{y^{j}}{l^{j}}
\end{aligned}
$$

so that, with constant returns to scale at the firm's level, profits $\pi^{j}$ are zero in equilibrium.

\subsection{Households' behavior}

Households are indexed by $i=1,2, \ldots, I$. Each household $i$ maximizes intertemporal utility:

$$
\int_{0}^{\infty} \log \left(c^{i}\right) e^{-\rho t} d t
$$

where $c^{i}$ is $i$ 's private consumption and $\rho>0$ is a time discount factor.

At each instant, household $i$ consumes, $c^{i}$, saves in the form of an asset, $a^{i}$, and allocates one unit of labor time ${ }^{12}$ between productive work and rent-seeking activities. Specifically, let $0<\eta^{i} \leq 1$ denote the fraction of $i$ 's time allocated to productive work and $0 \leq\left(1-\eta^{i}\right)<1$ the fraction allocated to rent seeking. The budget constraint is: ${ }^{13}$

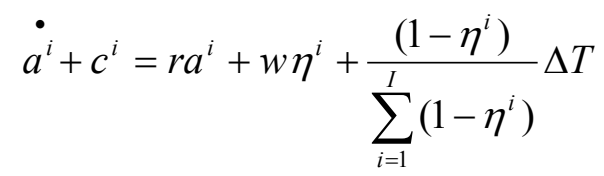

\footnotetext{
${ }^{12}$ For simplicity, we assume that each household has one unit of labor time available. Exogeneity of total labor time/effort justifies why leisure is not included in (4).

${ }^{13}$ A dot over a variable denotes a time derivative.
} 
where $T$ is foreign transfers and $0 \leq \Delta<1$ is the aggregate degree of extraction (see below for its determination). ${ }^{14}$ Equation (5) captures the idea that there is a perceived pie $\Delta T$, and then each individual tries to extract a fraction of it by competing with other individuals. ${ }^{15}$

Each household $i$ acts competitively taking prices $(r, w)$, policy $(T)$, and aggregate outcomes $\left(\sum_{i=1}^{I}\left(1-\eta^{i}\right), \Delta\right)$ as given. Combining the first-order conditions for consumption, saving and extraction $\left(c^{i}, a^{i}, \eta^{i}\right)$, we get:

$$
\begin{aligned}
& \dot{c^{i}}=c^{i}(r-\rho) \\
& w=\frac{\Delta T}{\sum_{i=1}^{I}\left(1-\eta^{i}\right)}
\end{aligned}
$$

where $(6 a)$ is a standard Euler equation and (6b) implies that net returns from work and appropriative competition are equal in equilibrium.

\subsection{The government budget constraint}

Assuming for simplicity a balanced budget, the government budget constraint is:

$$
G=\theta \sum_{j=1}^{J} y^{j}+(1-\Delta) T
$$

so that public services, $G$, are financed by domestic taxes, $\theta \sum_{j=1}^{J} y^{j}$, and the fraction of foreign aid that is not taken away by rent seekers, $(1-\Delta) T .^{16}$

\footnotetext{
${ }^{14}$ A positive value of $\Delta$ presupposes weak socio-economic institutions. To put it differently, there is a possibility of common access to a social resource (foreign aid).

${ }^{15}$ For a similar way of modeling appropriative competition, see e.g. Dasgupta and Heal (1979), Murphy et al. (1991), Grossman (2000), Svensson (2000), Grossman and Mendoza (2003) and Park et al. (2003).

${ }^{16}$ See also Chatterjee et al. (2003). As these authors point out, most aid programs are tied to specific public investment projects. This is, for instance, the case under the Structural Funds Program in the EU.
} 


\subsection{Decentralized competitive equilibrium}

This subsection will solve for a Decentralized Competitive Equilibrium (DCE) in a growing small open economy, for any foreign transfer policy and any feasible domestic policy. Specifically, a DCE is defined to be a Nash equilibrium in individuals' decisions in which: (i) each individual firm and household maximize their own profit and utility respectively by taking the actions of other individuals as given; (ii) all markets clear; ${ }^{17}$ (iii) individual decisions are consistent with aggregate decisions, ${ }^{18}$ (iv) all constraints, including the economy's resource constraint, are satisfied. For simplicity, we will focus on a symmetric DCE, i.e. in equilibrium private agents (firms and households) are alike. ${ }^{19}$ Thus, from now on, the superscripts $j$ and $i$ can be omitted. For notational simplicity, we also set $J=I \equiv 1$.

To get a closed-form solution for the DCE, we will choose - without loss of generality - a convenient specification for foreign transfers, $T$. In particular, we assume:

$T=\mu(\bar{y}-y)$

where $\mu>0$ is a redistribution parameter. According to the redistribution rule in (8a), foreign transfers $T$ paid to a country are a fraction of the deviation of that country's income, $y$, from worldwide average income, $\bar{y}$. If $\bar{y}>y$, the country is a recipient in the world economy; if $\bar{y}<y$, the country is a donor (our analysis will be in terms of a recipient country). ${ }^{20}$ Since the rest of the world is taken as given, we assume $\bar{y}=\lambda y$, where $\lambda>1$ is a measure of inequality

\footnotetext{
${ }^{17}$ That is, $\sum_{j} l^{j}=\sum_{i} \eta^{i}$ in the labor market and $\sum_{j} k^{j}=\sum_{i} a^{i}$ in the capital market. Note that, for simplicity, we assume away factor (labor and capital) mobility.

${ }^{18}$ Consistency of individual and aggregate decisions implies that, in equilibrium, the aggregate degree of extraction, $\Delta$, equals the total time spent in rent-seeking activities, $\sum_{i}\left(1-\eta^{i}\right)$. Thus, $\Delta=\sum_{i}\left(1-\eta^{i}\right)$. This is standard in general equilibrium models with externalities.

${ }^{19}$ Solving for a symmetric equilibrium is rich enough to capture incentive problems and show how non-cooperative and cooperative equilibria differ. See Park and Philippopoulos (2003) and the references cited therein.

${ }^{20}$ See Park and Philippopoulos (2003) and the references cited therein for similar state-contingent redistributive rules. The rule in (8a) is consistent with several institutional arrangements on foreign transfers, like those of the Structural Funds Program in the EU.
} 
between the domestic economy and the rest of the world. ${ }^{21}$ Obviously, $\lambda$ depends on a number of socio-economic factors, whose specification is an empirical matter (see e.g. Williamson, 1998); we will return to this issue in the empirical section below. In this section, we will solve for a DCE for given $\lambda$. Thus, the foreign aid-to-output ratio becomes:

$$
\frac{T}{y}=\mu(\lambda-1) \equiv \tau
$$

where $\tau \geq 0$ is an "effective redistribution" parameter.

We can now solve for a DCE. It is straightforward to show that (1)-(8) give: ${ }^{22}$

$$
\begin{aligned}
& \dot{c}=c\left[(1-\theta) \alpha A^{\frac{1}{\alpha}} \eta^{\frac{1-\alpha}{\alpha}}(\theta+\eta \tau)^{\frac{1-\alpha}{\alpha}}-\rho\right] \\
& \dot{k}=[1+\tau-(\theta+\eta \tau)] A^{\frac{1}{\alpha}} \eta^{\frac{1-\alpha}{\alpha}}(\theta+\eta \tau)^{\frac{1-\alpha}{\alpha}} k-c \\
& \eta=\frac{(1-\alpha)(1-\theta)}{\tau}
\end{aligned}
$$

Equations (9a)-(9c) give the paths of $(c, k, \eta)$ for any domestic economic policy, as summarized by the tax rate $0<\theta<1$, and any foreign transfer, as summarized by the redistribution parameter $\tau \geq 0$. $^{23}$

An advantage of the model is its simplicity. Equation (9c) gives $\eta$. If $\tau=(1-\alpha)(1-\theta)$, then $\eta=1$ so that all effort is allocated to work. If, on the other hand, $\tau>(1-\alpha)(1-\theta)$, then $0<\eta<1$ so that only a fraction of effort is allocated to work. In other words, there is rentseeking activity $(0<\eta<1)$, only if the foreign aid-to-output ratio $(\tau)$ and/or the domestic tax rate $(\theta)$ are high enough. ${ }^{24}$ In turn, having solved for $\eta,(9 a)$ can give the so-called balanced

\footnotetext{
${ }^{21}$ We set $\lambda>1$ because the analysis is in terms of a recipient country. Note that the functional specification in (8a)(8b) does not violate the linear structure of the model, and hence allows us to get a closed-form analytical solution for the competitive equilibrium, as in Barro-type models.

22 (9a) is the Euler equation. (9b) is the economy's resource constraint, $\dot{k}=y+T-G-c$.

${ }^{23}$ If $\tau=0$ and $\eta=1$, we get Barro's (1990) model.

${ }^{24}$ Conditions for rent seeking like this are usual in the literature. For instance, in models of social conflict, it is optimal to follow appropriative, non-cooperative behavior when assets to be appropriated are relatively high (for a survey, see Drazen, 2000, chapter 10.7). Therefore, as in most of the literature, we first assume that it is possible for
} 
growth path, $\gamma \equiv \frac{\dot{c}}{c}=\frac{\dot{k}}{k}$, and (9b) can give the consumption-to-capital ratio, $\frac{c}{k}$. Inspection of (9a) and (9b) reveals that cases with rent seeking $(0<\eta<1)$ are associated with a lower growth rate and a lower consumption-to-capital ratio than cases without rent seeking $(\eta=1)$.

We will close with comparative static results. It is intuitively convenient to consider first the benchmark non-interesting case without rent seeking, $\eta=1$. In this case, $\eta$ is obviously independent of the foreign aid-to-output ratio $(\tau)$, so that (9a) implies that there is only a direct positive effect from $\tau$ on the growth rate $(\gamma)$, denoted as $\frac{\partial \gamma}{\partial \tau}$. Regarding the effects of the tax rate $(\theta), \eta$ is also independent of $\theta$, so that (9a) gives a Laffer curve effect from $\theta$ on $\gamma$, denoted as $\frac{\partial \gamma}{\partial \theta}^{\text {Laffer }}$, as in Barro (1990).

Consider next the case with rent seeking, $0<\eta<1$. Now, (9c) implies $\frac{\partial \eta}{\partial \tau}<0$. That is, a higher foreign aid-to-output ratio leads to a lower fraction of effort allocated to work relative to rent seeking. In turn, (9a) implies ${\frac{\partial \gamma^{\text {total }}}{\partial \tau}}^{=} \frac{\partial \gamma}{\partial \tau}^{(+)}+\frac{\partial \gamma}{\partial \eta} \frac{\partial \eta}{\partial \tau}$. That is, an increase in $\tau$ exerts two effects on growth, $\gamma$ : (i) a direct positive effect; (ii) an indirect negative effect through smaller effort allocated to work, $\frac{\partial \gamma}{\partial \eta} \frac{\partial \eta}{\partial \tau}<0$. The direct positive effect arises because foreign aid finances public infrastructure. The indirect negative effect arises because aid transfers distort the incentives of self-interested individuals. Specifically, the possibility of extraction pushes them away from productive work to appropriative competition. Then, as the amount of transfers increases, individuals (who do not internalize the adverse effect of their rent-seeking activities on aggregate outcomes) become more aggressive. This is at the society's expense for two reasons: first, it reduces the resources available for public infrastructure (by increasing $\Delta$ ); second, it distorts individual incentives (by reducing $\eta$ ).

individuals to have access to a common-pool resource (e.g. aid); we then specify the conditions under which this possibility distorts incentives and leads to anti-social activities. 
Finally, the effects of the domestic tax rate are similar to those of foreign aid. Namely, (9c) implies $\frac{\partial \eta}{\partial \theta}<0$, i.e. a higher tax rate distorts incentives. In turn, (9a) implies that there are two effects on growth, $\gamma:$ a direct Laffer-curve effect and a negative indirect effect via a lower

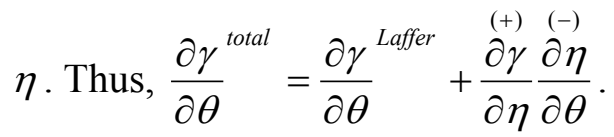

To sup up, when the foreign aid-to-output ratio and/or the domestic tax rate are sufficiently high, we end up in a bad equilibrium with rent seeking competition. This exerts an indirect negative effect on growth, which works in opposite direction from the direct positive effect that aid typically has on growth.

\section{Econometric specification and description of data}

This section will develop an empirical framework suitable to test the predictions of the theoretical model (9a)-(9c). The key prediction is that a rise in foreign aid transfers has a direct positive effect on growth by enhancing public infrastructure, but it also has an indirect negative effect by pushing individuals in recipient countries to rent-seeking activities. By using a cross-country dataset (see subsection 3.2 below for data description), we will search for these two opposite effects in the context of an econometric model that determines jointly the rate of economic growth, rent seeking activities and foreign aid transfers.

As Svensson (2000) points out, any test of this form is bound to be only suggestive for several reasons. For instance, long-term time series observations are not available for aid and rent seeking, and thus the analysis can only be confined to the medium-term impact of these variables on growth. In addition, rent-seeking activities are hard, if possible at all, to measure. Hence, any empirical methodology can only utilize proxy variables, which can hopefully provide adequate description of this type of activities.

\subsection{From theory to testing}

We consider linear regressions of the form: ${ }^{25}$

\footnotetext{
${ }^{25}$ Equations (10a) and (10b) follow from (9a) and (9c) respectively. We omit (9b), which gives the consumption-tocapital ratio, because data for capital stocks are not available for most aid-recipient economies. The regressions in
} 
growth rate $=G($ rent seeking, aid, tax rate; control variables $)$

rent seeking $=R$ (aid, tax rate; control variables)

According to the comparative static properties of (9a)-(9c), and focusing on cases with rent seeking, we expect a positive sign for aid and a negative sign for rent seeking in the growth regression (10a), combined with a positive sign for aid in the rent-seeking regression (10b). Also, a higher domestic tax rate is expected to increase rent seeking activities in (10b), whereas the (Laffer curve) effect of the tax rate on growth is ambiguous in (10a).

Equation (8b) suggest that aid transfers (specifically, the foreign aid-to-output ratio) to a particular country increase with its inequality vis-à-vis the rest of the world. Several authors have also pointed out the potential pitfalls associated with simultaneity bias when aid is treated as an exogenous variable in growth regressions; this accords with the approach adopted by Burnside and Dollar (2000). ${ }^{26}$ We will therefore assume that aid is jointly determined with growth and rent seeking. ${ }^{27}$ In particular, we will consider a linear regression of the form (where a measure of inequality will be defined in subsection 3.2. below):

aid $=$ A(inequality; control variables)

To control for other possible determinants of the endogenous variables in (10a)-(10c), we follow standard practice and include a number of auxiliary determinants (control variables); their choice is mainly dictated by the studies of Burnside and Dollar (2000), Svensson (2000), Alesina and Weder (2002) and Persson and Tabellini (2003, chapter 3). Control variables will include country characteristics like the initial level of per capita GDP, regional dummies, population size, as well as measures of ethnic conflict and political instability. ${ }^{28}$

(10a)-(10b) are similar to those in Leite and Weidmann (2002). The difference is that, in their paper, the driving force of corruption is natural resource abundance.

${ }^{26}$ For a survey of the empirical literature, see Hansen and Tarp (2001). These authors stress that with a 5-year average data sample (as the one utilized here) treating aid as endogenous, but predetermined, implies that any decisions on the allocation of aid are made on the basis of a 5 to 6 year planning horizon. We maintain this assumption here but we will also report - for comparison purposes - some results when aid is exogenous.

27 Svensson (1999) studies the simultaneous determination of growth, aid and a democracy index. He also emphasizes the importance of the endogenous determination of aid and democracy.

${ }_{28}$ Although the inclusion of these control variables is standard, it is useful to provide briefly our own explanations. First, we will use the initial GDP per capita to control for standard convergence arguments, as well as for recipient countries' needs and motives (see also Svensson, 2000). Second, regional dummies typically capture geographical and historical characteristics of the countries examined. Following Burnside and Dollar (2000), we will include dummies for Sub-Saharan countries and East-Asian countries in the growth equation. The same regional dummies 
As far as the estimation method is concerned, most of the literature relies on Instrumental Variable techniques or Panel methods with fixed effects. Taking into account the data availability and the nature of variables utilized, which are largely time-invariant, we will opt for 2SLS estimations in the pooled cross-section (with a core set of instruments consisting of regional dummies, initial GDP, population, government size, as well as measures of ethnic diversity, political instability and openness). This approach aims at capturing the possible endogeneity of rent seeking and aid in the context of growth regressions. In addition, we will report 3SLS results, since the simultaneous estimation of the system (compared to an equation-by-equation estimation method like 2SLS) has the advantage of not imposing any restrictions on the correlation between the error terms, which may improve the estimates on grounds of efficiency in the case of nonzero elements in the variance-covariance matrix. This might be important in the current setup (where, for instance, an unexpected shock in aid can be correlated with the disturbance in the growth equation).

\subsection{Description of data}

The data used come mainly from three sources: the Penn World Tables, version 6.1 (Heston et al., 2002), the IRIS data set (obtained by countrydata.com), and the World Bank database on aid developed by Chang et al. (1998).

The Penn World Tables provide us a number of variables. The GDP per capita in constant prices is used to obtain five-year average growth rates (denoted as growth rate in the Tables), the $\log$ of initial GDP per capita (denoted as $\lg d p$ ) and the log of population (denoted as lpop). In the theoretical model, the tax rate is a measure of the size of the government in a particular country. Following most of the literature, we will instead use government spending as a percentage of the

will be used in the rent-seeking equation along with a dummy for Central American countries. Again following Burnside and Dollar (2000), the aid equation will include a dummy for Central American countries (which are closely linked to the US), as well as two additional dummies, one for Egypt (an important ally of the US) and one for the Franc zone countries (which are closely linked to France). Persson and Tabellini (2003) use similar regional dummies to capture the effects of colonial history. Third, population size (in logs) will be included in the aid equation to capture possible scale effects, as countries with smaller populations are more likely to receive relatively large aid transfers due to donors' strategic interests like voting in international organizations. Finally, measures of ethnic diversity and political instability will be included in all three equations. Ethnic diversity is supposed to capture the ethno-linguistic fractionalization of groups within a country, which is correlated with bad policies and low growth (Easterly and Levine, 1997). It also takes into account Svensson's (2000) finding that aid in countries suffering from competing social groups is associated with rent seeking. In turn, political turmoil will be used to capture civil unrest, which is also believed to affect growth (Drazen, 2000). Another variable, usually related to economic conditions and policies, is openness. Measures of all these variables will be defined in subsection 3.2 below. 
country's GDP, as a measure of the size of its government. ${ }^{29}$ This will give us a five-year average of a variable denoted as government size. To get a measure of inequality in the aid regression (10c), we will use the recipient country's log of initial per capita income, $\lg d p$, and the log of initial per capita income in high-income OECD countries (following the World Bank classification), denoted as ldon. Aid transfers are expected to decrease with the former and increase with the latter, reflecting the idea that as the donors' income increases, aid increases. Finally, we define a country's openness as the sum of exports plus imports over GDP in constant prices, and then obtain five-year averages.

The source for aid data is the World Bank database on foreign aid. The files included in this database contain the conventional and the adjusted measures of official development assistance to a set of 133 countries between 1975 and 1995. The principal component of this dataset is Effective Development Assistance (EDA), an aggregate measure of aid flows combining total grants and the grant equivalents of all official loans. EDA is computed on a loanby-loan basis to reflect the financial cost the creditor incurs in making loans on concessional terms. Details on this variable are in Chang et al. (1998). By use of this dataset, we construct five-year averages of a variable denoted as aid (the ratio of EDA, in current units, to current GDP).

To obtain a measure of rent seeking, we use the IRIS dataset (version IRIS-3). This contains annual values for indicators of quality of governance, corruption and violation of property rights over the period 1982-1997, as constructed by Stephen Knack and the IRIS Center, University of Maryland, from monthly ICRG data provided by Political Risk Services. ${ }^{30}$ This dataset has been used by, among others, Knack and Keefer (1995), Svensson (2000), Alesina and Weder (2002), Fredriksson and Svensson (2003), Tavares (2003) and Barro and Sala-i-Martin (2004). Following most of the literature, we take the sum of five subjective indices available by the IRIS dataset: namely, "corruption in government", "rule of law", "risk of repudiation of government contracts", "risk of expropriation" and "quality of bureaucracy". From these indices,

\footnotetext{
${ }^{29}$ For many developing countries, data on tax revenues are limited. Persson and Tabellini (2003, pp. 49-50) find that tax revenue in a given country in nominal terms is more sensitive than government expenditure to the state of the economy implying a smaller reaction when both measures as scaled to GDP. Also, notice that Tanzi and Schuknecht (2000) use government expenditure as a percentage of GDP, which includes interest payments. However, since this is not available for all non-OECD countries, we use government spending.

${ }^{30}$ Obviously, rent seeking can take a variety of forms other than corruption, bureaucracy or property risks. This type of data, however, is not available at any form. Apart from data non-availability, our choice is also motivated by
} 
"corruption in government", "rule of law", and "quality of bureaucracy" range in value from 0 to 6 , whereas "risk of repudiation of government contracts" and "risk of expropriation" are scaled from 0 to 10 with higher values indicating better ratings, i.e. less corruption and less rent seeking. We then construct a new variable (measured at a 50-point scale) by converting "corruption in government", "rule of law", and "quality of bureaucracy" to a 10-point scale, and then adding them up to the other two indices. The resulting sum is finally averaged for each country for each 5 -year period and multiplied by (-1) to give a measure of rent-seeking activities (denoted as rent seeking) in the society at large. Finally, from the same dataset, we also use an index of ethnic diversity (denoted as ethnic). Following related studies (see e.g. Knack and Keefer, 1995), we also utilize a measure of political instability measured by the average number of political assassinations per million people per year (denoted as assassinations).

\section{Empirical evidence from pooled cross-section data}

We have collected 283 observations for 75 aid recipient countries for which rent seeking is available with each country having at most four observations. We will present results by treating all 75 countries as one group (in subsections 4.1. and 4.2) and then partition them into subgroups (in subsection 4.3).

\subsection{Empirical results}

Table 1 presents results from the estimation of the basic model (10a)-(10c). Although this is a system of equations, we start with OLS estimates to make our results comparable to those of the related literature (OLS estimates are reported in the first column next to each equation). The OLS estimates pinpoint a positive sign for aid and a negative sign for rent seeking in the growth equation. However, the effect of aid on rent seeking is insignificant in the rent seeking equation. Some other effects should also be noticed. The coefficients of ldon and lpop in the aid equation have the right signs and are significant at the 5\% level. In fact, the hypothesis that the coefficients on lgdp and ldon are equal and of opposite sign, as predicted by (8a), cannot be rejected by a standard F-test at the 1\% significance level. Thus, the redistribution rule assumed in ( $8 \mathrm{a})$ is not inconsistent with the data. The coefficient on the government size is significantly negative in the

Svensson's (2000) point that in practice there is no discrimination between the various forms of rent seeking, as presumably the competing groups equalize marginal costs and benefits between these forms. 
growth equation, and positive (though insignificant) in the rent seeking equation. Concerning control variables, their coefficients have the expected signs and are significant in most cases. For instance, ethnic tensions and assassinations are significant in the rent seeking equation with positive signs. Also, $\lg d p$ enters with a statistically significant negative sign in all equations. The dummies for Sub-Saharan and East-Asian countries are also significant with expected signs in the growth and rent seeking equations.

We continue with 2SLS estimations (reported in the second column next to each specification). Observe that now, as predicted by the theory, aid exerts a positive and significant effect on rent seeking. ${ }^{31}$ Also, the coefficients on aid and rent seeking in the growth equation have the expected signs and are significant. Combining estimation results, the coefficient on aid implies that a rise of aid transfers as a percentage of GDP by one point would raise the growth rate by around 0.5 points in the absence of rent-seeking activities. However, rent-seeking activities also rise as a result of higher aid, so that the net effect of aid on the growth rate is eventually smaller: a rise of aid-to-GDP ratio by one percentage point raises the growth rate by 0.3 percentage points only, ${ }^{32}$ when the adverse effect of rent seeking is also taken into account.

Regarding the size of the government and its impact on growth and rent-seeking, government size enters with a statistically significant negative sign in the growth equation with a coefficient value of -0.108 , which is not far to that obtained by other growth studies; in other words, ceteris paribus, an increase in the size of government by 1 percentage point of GDP will reduce the growth rate on impact by roughly 0.11 percentage points on an annual basis. ${ }^{33}$ By contrast, the coefficient on government size in the rent seeking equation is significantly negative. Although this coefficient turns insignificant in all subsequent specifications (see below), this is somewhat against our theoretical predictions. A possible explanation could be the inclusion of $\lg d p$ in the estimated equation; Mauro (1998) shows that when one controls for initial GDP, the significance of public spending (with the exception of education expenditures) in explaining corruption is reduced substantially. Finally, observe that, relative to the OLS estimates, the

\footnotetext{
${ }^{31}$ See also Alesina and Weder (2002, p. 1135) who argue that “...an increase in aid is associated with an increase in corruption and vice versa..."). Moreover, the lack of statistical significance of rent seeking in the aid equation confirms the finding by the same authors that there is no evidence that more corrupt countries receive less aid. The combined evidence reinforces the view that the causation runs from aid transfers to rent-seeking activities, and this is further strengthened by the insignificance of aid in the rent seeking equation when aid enters as an exogenous variable (see the results from the OLS specification).

${ }^{32}$ The net effect is obtained by subtracting the product of the coefficients on rent seeking (in the growth equation) and aid (in the rent seeking equation) from the coefficient on aid in the growth equation.
} 
estimated coefficients on control variables and regional dummies retain their signs and significance levels, with the exception of the dummy for East-Asian countries in the growth equation, which is now insignificant (see also Burnside and Dollar, 2000).

We also estimate the system (10a)-(10c) by using 3SLS to account for non-zero correlations in the unexplained parts of the regressions (results are reported in the third column next to each specification). All coefficients remain roughly unchanged, with the exception of the coefficient on government size in the rent seeking equation, which becomes insignificant. Regarding the coefficients of main interest, a rise in aid again leads to an increase in rent seeking (with a somewhat larger coefficient now), whereas aid and rent seeking appear with similar (though slightly larger) coefficients in the growth equation. The net effect, however, of a rise in the aid-to-GDP ratio by one percentage point on the growth rate remains remarkably close to the one found with 2SLS, indicating that the overall picture is confirmed when the equations are estimated jointly, as long as aid and rent-seeking activities are being treated endogenously.

\subsection{Robustness and extensions}

We have performed several robustness tests, all of which confirm the above multivariate relationship between growth rate, rent seeking and aid. Table 2 reports a subset of these tests (estimated by 3 SLS). ${ }^{34}$ The changes are the inclusion of assassinations and ethnic in the growth equation, and the inclusion of openness in all three equations. The first modification stems from Burnside and Dollar (2000) and aims at capturing long-term characteristics affecting growth, civil status and policies. The second modification allows for the widely established positive correlation between various measures of openness and economic growth. These variables are often included in empirical growth and aid equations. ${ }^{35}$

\footnotetext{
${ }^{33}$ For instance, Barro (2001) reports a corresponding coefficient of -0.157 in his equation for the growth rate.

${ }^{34}$ Apart from the robustness checks reported below, our tests also involved the use of alternative definitions for the variables measuring aid and rent seeking. For instance, we experimented with the two other measures of aid available by the World Bank, namely Bilateral EDA and Multilateral EDA (see Chang, 1998, for the description of these variables) without any significant changes in the results. We also used the property rights index (available from ICRG), which is the sum of rule of law and expropriation risk, as suggested by Knack and Keefer (1995), and the results remained similar. In addition, we tested the robustness of our results for the possible effect of outliers by dropping one suspected country at a time. None of the resulting regressions for each equation is significantly different from the regressions presented in the paper after the exclusion of the following list of countries (observations), which had the highest residuals: Jordan (1975, 1980), Zaire (all observations), Philippines (all observations), Botswana (1975), Uganda (1980), Gabon: (1975, 1980), Guinea-Bissau (1975).

${ }^{35}$ Along this line we could include the Burnside and Dollar (2000) "good policy" index as an additional variable in the growth and aid equations. We do not do it because two of the three determinants of the policy index, namely the
} 
In the first column of Table 2, both assassinations and ethnic are found to be insignificant in the growth equation, in line with the findings by Burnside and Dollar (2000). In the second column, the coefficient on openness is significant in the growth equation, but insignificant in the rent seeking equation. Results do not change when all three variables are included in the growth equation.

Interestingly, estimates of the coefficient on aid in the growth equation become less significant when openness is included, whereas the coefficient on aid in the rent seeking equation becomes larger in magnitude (and always significant at the 5\% level). Consequently, the net effect of aid upon growth is now close to zero. It thus appears that differences in the degree of openness among aid-recipient countries can be an important determinant of the impact of aid flows on rent-seeking activities. A potential explanation offered by Neeman et al. (2003) is that, in today's open economies, corrupt agents can transfer stolen money outside of the country, thus depleting their country's capital stock.

\subsection{Do aid-recipient countries differ?}

So far we have treated all 75 aid-recipient countries as a single group. Recall however that the theoretical model distinguishes two cases: those that receive relatively large aid transfers and/or have large public sectors; and those that receive relatively small aid transfers and/or have small public sectors. Only in the former case, aid and government size can trigger rent-seeking activities. In the latter case, rent-seeking activities (if any) are expected to be independent of aid and government size, so that only the direct positive effect from aid upon growth should be present.

To test for such differences across countries, we have to partition them on the grounds of the amount of aid they get, or the size of their public sector, or a combination of both. We have experimented with various definitions of "small" and "large" aid transfers in the data (namely, with different critical values of aid below which it would be possible that rent seeking is not affected by aid) but the data do not distinguish different groups. This can be justified by the nature of the countries included in the dataset, all of which are "large" aid recipients. Therefore, we do not partition countries into groups on the criterion of how much aid they get.

degree of openness and the budget surplus, are captured by the existing independent variables leaving only the less significant component of the index (inflation) out. 
The empirical analysis becomes more interesting when we partition countries according to the size of their public sector. Table 3 checks this hypothesis where, for comparison purposes, we adopt both the core specification of Table 1, as well as the extended specification of Table 2 that includes assassinations, ethnic and openness. These are reported in the first and second column under "large" and "small" government using 121 and 162 observations respectively, with the average government size of the sample taken as the breaking point. In line with the theoretical predictions, the empirical results indicate that, in countries with "large" public sectors, aid affects rent seeking positively; the coefficients of aid are significant in both specifications, although somewhat lower in magnitude compared to the ones reported for the full sample. In contrast, this effect evaporates in countries with "small" public sectors, where the coefficients are insignificant. This implies that the previously established adverse effect of foreign aid transfers on rent-seeking behavior is mainly driven by countries with larger-than-average public sectors.

Turning to the growth equation, rent seeking affects growth negatively irrespectively of government size. In line with the findings in Tables 1 and 2, the estimated coefficients on rent seeking are significant, with those in the core specification being smaller in magnitude than those in the extended specification for both groups of countries. The evidence is slightly less strong concerning the growth effect of aid: the estimated coefficients are significant for countries with "large" public sectors, while in countries with "small" public sectors, where the aid effect is found to be larger, they are only marginally significant (in the core specification at $10 \%$ level only). ${ }^{36}$

To sum up, the data support the theoretical prediction that countries with large public sectors differ from countries with small public sectors. Evidently, in countries with large public sectors, foreign aid triggers rent seeking competition. Although our findings should be interpreted with some caution, they seem to confirm the common belief that rent seeking from aid transfers takes place via state coffers, and this gets easier when the size of public sector is relatively large. We believe that the link among aid, fiscal management and incentives requires further research.

\footnotetext{
${ }^{36}$ This may shed some light in the context of Rodrik's (1998) finding that a rise in openness is associated with an increase in the size of government. An explanation put forward by Rodrik was that in countries, which are more vulnerable to external shocks, the government sector can mitigate risk by taking command of a larger share of the economy's resources. Along these lines, the evidence presented in Table 3 may bear a complementary explanation, particularly for aid-recipient countries. Namely, aid increases openness and hence provides more scope for government activities, thus rendering the adverse effect on rent-seeking (and growth) stronger.
} 


\section{Conclusions and policy implications}

We investigated the interrelationship between growth, rent seeking and foreign aid. The primary focus was to explain the poor performance of aid flows in terms of economic growth. To this end, we constructed a general equilibrium model of endogenous growth in which foreign aid can also distort individuals' incentives by pushing them to socially destructive activities. This indirect adverse effect can offset the direct positive impact of aid. Next, we tested this hypothesis for a cross-section of countries where measures of rent seeking are available. The data support the main prediction: aid is far less effective in improving growth when its indirect distortion in incentives is taken into account.

We close with some brief policy remarks. Although our findings show the adverse effects of aid on incentives, this should not be taken as a message against the provision of aid. If there is a policy message, this is against poor domestic public institutions, which facilitate the distortion of individual incentives, and so an argument for conditional aid, where conditionality focuses on transparency and good functioning of the public sector in aid-recipient countries (see Svensson, 2003, for conditional aid; see also the discussion in Fischer, 2003). By the same argument, greater weight should be placed in the role of independent institutions and NGOs in delivering aid, thus leaving less room for distorted intervention in the allocation of transferred amounts. All this is consistent with the ongoing discussion about the effectiveness of aid under a "good" policy environment (see the comment by Easterly et al., 2004, and the reply by Burnside and Dollar, 2004). 


\section{REFERENCES}

Alesina A. and B. Weder (2002): Do corrupt governments receive less foreign aid, American Economic Review, 92, 1126-1137.

Barro R. (1990): Government spending in a simple model of economic growth, Journal of Political Economy, 98, S103-S125.

Barro R. (2001): Human capital and growth, American Economic Review, 91, 12-17.

Barro R. and X. Sala-i-Martin (2004): Economic Growth. Second edition. The MIT Press, Cambridge, Mass.

Baumol W. (1990): Entrepreneurship: Productive, unproductive, and destructive, Journal of Political Economy, 98, 893-921.

Boone P. (1996): Politics and the effectiveness of foreign aid, European Economic Review, 40, 289-329.

Burnside C. and D. Dollar (2000): Aid, policies and growth, American Economic Review, 90, 847-868.

Burnside C. and D. Dollar (2004): A reply to new data, new doubts: A comment on Burnside and Dollar's 'Aid, Policies, and Growth', American Economic Review, forthcoming.

Chang C., E. Fernandez-Arias and L. Serven (1998): Measuring aid flows: A new approach, Working paper, Development Research Group, World Bank.

Chatterjee S., G. Sakoulis and S. Turnovsky (2003): Unilateral capital transfers, public investment and economic growth, European Economic Review, 47, 1077-1103.

Dasgupta P. and G. Heal (1979): Economic Theory and Exhaustible Resources, Cambridge University Press, Cambridge.

Drazen A. (2000): Political Economy in Macroeconomics, Princeton University Press, Princeton, New Jersey.

Easterly W. (2001): The Elusive Quest for Growth, MIT Press, Cambridge, Mass.

Easterly W. and R. Levine (1997): Africa's growth tragedy: Policies and ethnic divisions, Quarterly Journal of Economics, 112, 1203-1250.

Easterly W., R. Levine and D. Roodman (2004): New data, new doubts: A comment on Burnside and Dollar's 'Aid, Policies, and Growth', American Economic Review, forthcoming.

Fischer S. (2003): Globalization and its challenges, American Economic Review, Papers and Proceedings, 93, 1-30. 
Fredriksson P.G. and J. Svensson (2003): Political instability, corruption and policy formation: The case of environmental policy, Journal of Public Economics, 87, 1383-1405.

Grossman H. (2000): The creation of effective property rights, Working Paper, no. 00-15, Brown University, Providence.

Grossman H. and M. Kim (1996): Predation and accumulation, Journal of Economic Growth, 1, 333-350.

Grossman H. and J. Mendoza (2003): Scarcity and appropriative competition, European Journal of Political Economy, 19, 747-758.

Hansen H. and F. Tarp (2001): Aid and growth regressions, Journal of Development Economics, 64, 547-570.

Heston A., R. Summers and B. Aten (2002): Penn World Table Version 6.1, Center for International Comparisons at the University of Pennsylvania (CICUP).

Knack S. and P. Keefer (1995): Institutions and economic performance: Cross-country tests using alternative institutional measures, Economics and Politics, 7, 207-227.

Knack S. and P. Keefer (1997): Does social capital have an economic payoff? A cross-country investigation, Quarterly Journal of Economics, 112, 1251-1287.

Leite C. and J. Weidmann (2002): Does mother nature corrupt? Natural resources, corruption and economic growth, in Governance, Corruption and Economic Performance, edited by G. Abed and S. Gupta, International Monetary Fund, Washington, D.C.

Mauro P. (1995): Corruption and growth, Quarterly Journal of Economics, 110, 681-712.

Mauro P. (1998): Corruption and the composition of government expenditures, Journal of Public Economics, 69, 263-279.

Mauro P. (2002): The persistence of corruption and slow economic growth, IMF Working Paper 02/213, Washington, D.C.

Moreira S. (2003): Evaluating the impact of foreign aid on economic growth: A cross-country study (1970-1988), paper presented at the $15^{\text {th }}$ Annual Meeting on Socio-Economics.

Mosley P. (1986): Aid effectiveness: The micro-macro paradox, Institute of Development Studies Bulletin, 17, 22-27.

Mosley P., J. Hudson and S. Horrell (1987): Aid, the public sector and the market in less developed countries, Economic Journal, 97, 616-641. 
Murphy K., A. Shleifer and R. Vishny (1991): The allocation of talent: Implications for growth, Quarterly Journal of Economics, 106, 503-530.

Neeman Z., D. Paserman and A. Simhon (2003): Corruption and openness, CEPR Discussion Paper, no. 4057, London.

Park H. and A. Philippopoulos (2003): On the dynamics of growth and fiscal policy with redistributive transfers, Journal of Public Economics, 87, 515-538.

Park H., A. Philippopoulos and V. Vassilatos (2003): On the optimal size of public sector under rent-seeking competition from state coffers, CESifo Working Paper, no. 991, Munich.

Persson T. and G. Tabellini (2003): The Economic Effects of Constitutions. The MIT Press, Cambridge, Mass.

Rodrik D. (1998): Why do more open economies have bigger governments?, Journal of Political Economy, 106, 997-1032.

Svensson J. (1999): Aid, growth and democracy, Economics and Politics, 11, 275-297.

Svensson J. (2000): Foreign aid and rent-seeking, Journal of International Economics, 51, 437461.

Svensson J. (2003): Why conditional aid does not work and what can be done about it? Journal of Development Economics, 70, 381-402.

Tavares J. (2003): Does foreign aid corrupt?, Economics Letters, 79, 99-106.

Tanzi V. and L. Schuknecht (2000): Public Spending in the 20th Century: A Global Perspective, Cambridge University Press, Cambridge.

Tanzi V. (2002): Corruption around the world: Causes, consequences, scope and cures, in Governance, Corruption and Economic Performance, edited by G. Abed and S. Gupta, International Monetary Fund, Washington, D.C.

Williamson J. (1998): Globalization and the labor market: Using history to inform policy, in Growth, Inequality and Globalization, edited by P. Aghion and J. Williamson, Cambridge University Press, Cambridge.

World Bank (1998): Assessing Aid: What Works, What Doesn't, And Why. Oxford University Press, New York.

Zak P. and S. Knack (2001): Trust and growth, Economic Journal, 111, 295-321. 
TABLE 1. Estimates of the aid impact on growth and rent-seeking: core model (1975-1995, 283 observations)

\begin{tabular}{|c|c|c|c|c|c|c|c|c|c|c|c|}
\hline $\begin{array}{l}\text { Dep. variable: } \\
\text { growth rate }\end{array}$ & $O L S$ & $2 S L S$ & $3 S L S$ & $\begin{array}{l}\text { Dep. variable: } \\
\text { rent-seeking }\end{array}$ & $O L S$ & $2 S L S$ & $3 S L S$ & $\begin{array}{l}\text { Dep. variable: } \\
\text { aid }\end{array}$ & $O L S$ & $2 S L S$ & $3 S L S$ \\
\hline constant & $\begin{array}{c}11.540 * * \\
(3.61)\end{array}$ & $\begin{array}{c}11.673 * * \\
(3.08)\end{array}$ & $\begin{array}{c}11.740 * * \\
(3.14)\end{array}$ & constant & $\begin{array}{c}16.489 * * \\
(4.14)\end{array}$ & $\begin{array}{c}10.464 * * \\
(2.25)\end{array}$ & $\begin{array}{c}9.890 * * \\
(2.18)\end{array}$ & constant & $\begin{array}{l}9.879 \\
(1.10)\end{array}$ & $\begin{array}{l}9.730 \\
(1.08)\end{array}$ & $\begin{array}{l}10.541 \\
(1.27)\end{array}$ \\
\hline $\lg d p$ & $\begin{array}{c}-1.508^{* *} \\
(-3.51)\end{array}$ & $\begin{array}{c}-1.742 * * \\
(-2.67)\end{array}$ & $\begin{array}{c}-1.863^{* *} \\
(-2.90)\end{array}$ & $\lg d p$ & $\begin{array}{c}-4.676^{* *} \\
(-9.48)\end{array}$ & $\begin{array}{c}-3.767 * * \\
(-6.30)\end{array}$ & $\begin{array}{c}-3.863 * * \\
(-6.64)\end{array}$ & $\lg d p$ & $\begin{array}{c}-1.799 * * \\
(-9.28)\end{array}$ & $\begin{array}{c}-1.695^{* *} \\
(-6.19)\end{array}$ & $\begin{array}{c}-1.649^{* *} \\
(-6.16)\end{array}$ \\
\hline Sub-Saharan & $\begin{array}{c}-3.499 * * \\
(-5.82)\end{array}$ & $\begin{array}{c}-4.020 * * \\
(-5.19)\end{array}$ & $\begin{array}{c}-4.369 * * \\
(-5.76)\end{array}$ & Sub-Saharan & $\begin{array}{c}-3.536 * * \\
(-4.63)\end{array}$ & $\begin{array}{c}-4.102 * * \\
(-4.91)\end{array}$ & $\begin{array}{c}-4.763 * * \\
(-5.98)\end{array}$ & lpop & $\begin{array}{c}-0.818 * * \\
(-9.08)\end{array}$ & $\begin{array}{c}-0.808 * * \\
(-8.77)\end{array}$ & $\begin{array}{c}-0.797 * * \\
(-8.96)\end{array}$ \\
\hline \multirow[t]{4}{*}{ East Asia } & $\begin{array}{c}1.894 * * \\
(2.58)\end{array}$ & $\begin{array}{l}1.568^{*} \\
(1.72)\end{array}$ & $\begin{array}{l}1.452 \\
(1.63)\end{array}$ & East Asia & $\begin{array}{c}-5.123 * * \\
(-5.61)\end{array}$ & $\begin{array}{c}-4.668^{* *} \\
(-4.73)\end{array}$ & $\begin{array}{c}-4.549 * * \\
(-4.90)\end{array}$ & Franc Zone & $\begin{array}{l}-0.114 \\
(-0.31)\end{array}$ & $\begin{array}{l}-0.088 \\
(-0.24)\end{array}$ & $\begin{array}{l}-0.020 \\
(-0.06)\end{array}$ \\
\hline & & & & Central America & $\begin{array}{c}2.378 * * \\
(2.91)\end{array}$ & $\begin{array}{c}2.440 * * \\
(2.79)\end{array}$ & $\begin{array}{c}2.337 * * \\
(2.77)\end{array}$ & $\begin{array}{l}\text { Central } \\
\text { America }\end{array}$ & $\begin{array}{c}-0.641 * \\
(-1.74)\end{array}$ & $\begin{array}{l}-0.736^{*} \\
(-1.80)\end{array}$ & $\begin{array}{c}-0.797 * * \\
(-2.00)\end{array}$ \\
\hline & & & & assassinations & $\begin{array}{c}7.650 * * \\
(3.99)\end{array}$ & $\begin{array}{c}7.470 * * \\
(3.64)\end{array}$ & $\begin{array}{c}7.084 * * \\
(3.72)\end{array}$ & Egypt & $\begin{array}{l}1.036 \\
(1.03)\end{array}$ & $\begin{array}{l}1.016 \\
(1.00)\end{array}$ & $\begin{array}{l}0.794 \\
(0.85)\end{array}$ \\
\hline & & & & ethnic & $\begin{array}{c}1.009 * * \\
(4.28)\end{array}$ & $\begin{array}{c}1.209 * * \\
(4.65)\end{array}$ & $\begin{array}{c}1.046^{* *} \\
(4.30)\end{array}$ & ldon & $\begin{array}{c}1.892 * * \\
(2.03)\end{array}$ & $\begin{array}{c}1.867 * * \\
(2.00)\end{array}$ & $\begin{array}{c}1.748 * * \\
(2.03)\end{array}$ \\
\hline $\begin{array}{l}\text { government } \\
\text { size }\end{array}$ & $\begin{array}{c}-0.086 * * \\
(-3.93)\end{array}$ & $\begin{array}{c}-0.108 * * \\
(-3.85)\end{array}$ & $\begin{array}{c}-0.098 * * \\
(-3.58)\end{array}$ & government size & $\begin{array}{l}-0.013 \\
(-0.49)\end{array}$ & $\begin{array}{c}-0.085^{* *} \\
(-2.30)\end{array}$ & $\begin{array}{l}-0.045 \\
(-1.29)\end{array}$ & & & & \\
\hline aid & $\begin{array}{c}0.275^{* *} \\
(2.85)\end{array}$ & $\begin{array}{c}0.493 * * \\
(2.43)\end{array}$ & $\begin{array}{c}0.549 * * \\
(2.75)\end{array}$ & aid & $\begin{array}{l}-\mathbf{- 0 . 0 0 3} \\
\mathbf{( - 0 . 0 3 )}\end{array}$ & $\begin{array}{c}0.785 * * \\
(2.84)\end{array}$ & $\begin{array}{c}0.876 * * \\
(3.29)\end{array}$ & & & & \\
\hline rent-seeking & $\begin{array}{c}-0.148 * * \\
(-3.44)\end{array}$ & $\begin{array}{c}-0.229 * * \\
(-2.25)\end{array}$ & $\begin{array}{c}-0.257 * * \\
(-2.57)\end{array}$ & & & & & rent-seeking & $\begin{array}{l}-0.037 \\
(-1.52)\end{array}$ & $\begin{array}{l}-0.014 \\
(-0.28)\end{array}$ & $\begin{array}{l}-0.006 \\
(-0.14)\end{array}$ \\
\hline
\end{tabular}

Notes: t-ratios are in parentheses. An asterisk denotes significance at the $10 \%$ level and two asterisks at the $5 \%$ level. 
TABLE 2. Estimates of the aid impact on growth and rent-seeking: robustness checks (3SLS, 1975-1995, 283 observations)

\begin{tabular}{|c|c|c|c|c|c|c|c|c|c|c|c|}
\hline \multicolumn{4}{|c|}{ Dep. variable: growth rate } & \multicolumn{4}{|c|}{ Dep. variable: rent-seeking } & \multicolumn{4}{|c|}{ Dep. variable: aid } \\
\hline constant & $\begin{array}{l}14.150 * * \\
(2.91)\end{array}$ & $\begin{array}{l}16.276^{* * *} \\
(4.10)\end{array}$ & $\begin{array}{l}18.442^{* *} \\
(3.64)\end{array}$ & constant & $\begin{array}{l}9.849 * * \\
(2.17)\end{array}$ & $\begin{array}{l}8.027 \\
(1.64)\end{array}$ & $\begin{array}{l}8.009 \\
(1.63)\end{array}$ & constant & $\begin{array}{r}10.756 \\
(1.29)\end{array}$ & $\begin{array}{l}9.420 \\
(1.13)\end{array}$ & $\begin{array}{r}9.483 \\
(1.14)\end{array}$ \\
\hline $\lg d p$ & $\begin{array}{l}-2.800^{* *} \\
(-2.42)\end{array}$ & $\begin{array}{l}-2.678^{* *} \\
(-3.86)\end{array}$ & $\begin{array}{l}-3.608^{* *} \\
(-3.06)\end{array}$ & $\lg d p$ & $\begin{array}{l}-3.842 * * \\
(-6.60)\end{array}$ & $\begin{array}{c}-3.566^{* *} \\
(-5.43)\end{array}$ & $\begin{array}{l}-3.550 * * \\
(-5.39)\end{array}$ & $\lg d p$ & $\begin{array}{c}-1.675^{* *} \\
(-6.24)\end{array}$ & $\begin{array}{c}-1.648 * * \\
(-6.11)\end{array}$ & $\begin{array}{l}-1.654^{* *} \\
(-6.13)\end{array}$ \\
\hline Sub-Saharan & $\begin{array}{l}-5.895 * * \\
(-4.13)\end{array}$ & $\begin{array}{l}-4.772 * * \\
(-6.07)\end{array}$ & $\begin{array}{l}-6.239^{* *} \\
(-4.36)\end{array}$ & Sub-Saharan & $\begin{array}{c}-4.817^{* *} \\
(-6.05)\end{array}$ & $\begin{array}{l}-4.424 * * \\
(-4.72)\end{array}$ & $\begin{array}{l}-4.740 * * \\
(-5.82)\end{array}$ & lpop & $\begin{array}{c}-0.799 * * \\
(-8.98)\end{array}$ & $\begin{array}{c}-0.770 * * \\
(-7.06)\end{array}$ & $\begin{array}{l}-0.770 * * \\
(-7.06)\end{array}$ \\
\hline East Asia & $\begin{array}{l}-0.004 \\
(-0.00)\end{array}$ & $\begin{array}{l}0.827 \\
(0.91)\end{array}$ & $\begin{array}{l}-0.573 \\
(-0.35)\end{array}$ & East Asia & $\begin{array}{l}-4.600 * * \\
(-4.95)\end{array}$ & $\begin{array}{c}-4.685 * * \\
(-5.76)\end{array}$ & $\begin{array}{l}-4.475^{* *} \\
(-4.77)\end{array}$ & Franc Zone & $\begin{array}{l}-0.021 \\
(-0.06)\end{array}$ & $\begin{array}{c}-0.004 \\
(-0.01)\end{array}$ & $\begin{array}{l}-0.003 \\
(-0.01)\end{array}$ \\
\hline assassinations & $\begin{array}{l}2.152 \\
(0.73)\end{array}$ & - & $\begin{array}{l}2.647 \\
(0.89)\end{array}$ & assassinations & $\begin{array}{l}7.153 * * \\
(3.73)\end{array}$ & $\begin{array}{l}6.930 * * \\
(3.68)\end{array}$ & $\begin{array}{l}7.131 * * \\
(3.72)\end{array}$ & Egypt & $\begin{array}{l}0.792 \\
(0.85)\end{array}$ & $\begin{array}{l}0.684 \\
(0.73)\end{array}$ & $\begin{array}{r}0.688 \\
(0.74)\end{array}$ \\
\hline \multirow[t]{2}{*}{ ethnic } & $\begin{array}{l}0.410 \\
(1.13)\end{array}$ & - & $\begin{array}{l}0.370 \\
(1.01)\end{array}$ & ethnic & $\begin{array}{l}1.068 * * \\
(4.37)\end{array}$ & $\begin{array}{l}1.105^{* *} \\
(4.37)\end{array}$ & $\begin{array}{l}1.120 * * \\
(4.37)\end{array}$ & ldonor & $\begin{array}{l}1.735^{* *} \\
(2.02)\end{array}$ & $\begin{array}{l}1.804 * * \\
(2.11)\end{array}$ & $\begin{array}{l}1.800^{* *} \\
(2.10)\end{array}$ \\
\hline & & & & $\begin{array}{l}\text { Central } \\
\text { America }\end{array}$ & $\begin{array}{l}2.176^{* *} \\
(2.57)\end{array}$ & $\begin{array}{l}2.481 * * \\
(2.91)\end{array}$ & $\begin{array}{l}2.275^{* *} \\
(2.65)\end{array}$ & $\begin{array}{l}\text { Central } \\
\text { America }\end{array}$ & $\begin{array}{r}-0.727^{*} \\
(-1.81)\end{array}$ & $\begin{array}{r}-0.740 * \\
(-1.83)\end{array}$ & $\begin{array}{l}-0.723^{*} \\
(-1.79)\end{array}$ \\
\hline openness & & $\begin{array}{l}0.020 * * \\
(2.84)\end{array}$ & $\begin{array}{l}0.018 * * \\
(2.20)\end{array}$ & openness & & $\begin{array}{l}-0.009 \\
(-0.97)\end{array}$ & $\begin{array}{l}-0.009 \\
(-0.96)\end{array}$ & openness & & $\begin{array}{l}0.001 \\
(0.43)\end{array}$ & $\begin{array}{r}0.001 \\
(0.43)\end{array}$ \\
\hline $\begin{array}{l}\text { government } \\
\text { size }\end{array}$ & $\begin{array}{l}-0.115^{* *} \\
(-3.08)\end{array}$ & $\begin{array}{l}-0.109 * * \\
(-3.98)\end{array}$ & $\begin{array}{l}-0.125^{* *} \\
(-3.29)\end{array}$ & $\begin{array}{l}\text { government } \\
\text { size }\end{array}$ & $\begin{array}{l}-0.046 \\
(-1.32)\end{array}$ & $\begin{array}{l}-0.044 \\
(-1.27)\end{array}$ & $\begin{array}{l}-0.045 \\
(-1.29)\end{array}$ & & & & \\
\hline aid & $\begin{array}{l}0.827 * * \\
(2.73)\end{array}$ & $\begin{array}{l}0.283 \\
(1.34)\end{array}$ & $\begin{array}{l}\text { 0.585* } \\
(1.80)\end{array}$ & aid & $\begin{array}{l}0.884 * * \\
(3.32)\end{array}$ & $\begin{array}{l}1.028 * * \\
(3.43)\end{array}$ & $\begin{array}{l}1.033 * * \\
(3.45)\end{array}$ & & & & \\
\hline rent-seeking & $\begin{array}{l}-0.532 * \\
(-1.95)\end{array}$ & $\begin{array}{l}-0.317 * * \\
(-3.12)\end{array}$ & $\begin{array}{l}-0.596 * * \\
(-2.19)\end{array}$ & & & & & rent-seeking & $\begin{array}{l}-0.011 \\
(-0.23)\end{array}$ & $\begin{array}{l}-0.006 \\
(-0.13)\end{array}$ & $\begin{array}{l}-0.007 \\
(-0.16)\end{array}$ \\
\hline
\end{tabular}

Notes: t-ratios are in parentheses. An asterisk denotes significance at the $10 \%$ level and two asterisks at the $5 \%$ level. 
TABLE 3. Estimates of the aid impact on growth and rent-seeking for 'large' (121 obs.) and 'small' (162 obs.) government size (3SLS, 1975-1995)

\begin{tabular}{|c|c|c|c|c|c|c|c|c|c|c|c|c|c|c|}
\hline \multirow{2}{*}{$\begin{array}{l}\text { Dep. variable: } \\
\text { growth rate } \\
\text { constant }\end{array}$} & \multicolumn{2}{|c|}{ "large" government } & \multicolumn{2}{|c|}{ “small” government } & \multirow{2}{*}{$\begin{array}{l}\text { Dep. variable: } \\
\text { rent-seeking }\end{array}$} & \multicolumn{2}{|c|}{ "large" government } & \multicolumn{2}{|c|}{ "small" government } & \multirow{2}{*}{$\begin{array}{l}\text { Dep. variable: } \\
\text { aid }\end{array}$} & \multicolumn{2}{|c|}{ "large" government } & \multicolumn{2}{|c|}{ "small" government } \\
\hline & $\begin{array}{l}11.031 * * \\
(2.20)\end{array}$ & $\begin{array}{l}14.791 * * \\
(2.14)\end{array}$ & $\begin{array}{l}8.975 \\
(1.15)\end{array}$ & $\begin{array}{l}16.366^{* * *} \\
(2.17)\end{array}$ & & $\begin{array}{l}5.602 \\
(0.88)\end{array}$ & $\begin{array}{l}6.144 \\
(0.88)\end{array}$ & $\begin{array}{c}12.369 * * \\
(1.26)\end{array}$ & $\begin{array}{l}8.585 \\
(0.92)\end{array}$ & & $\begin{array}{l}31.532 \\
(1.64)\end{array}$ & $\begin{array}{c}29.398 \\
(1.50)\end{array}$ & $\begin{array}{l}0.522 \\
(0.12)\end{array}$ & $\begin{array}{l}0.648 \\
(0.15)\end{array}$ \\
\hline $\lg d p$ & $\begin{array}{l}-1.797 * * \\
(-2.31)\end{array}$ & $\begin{array}{l}-3.606^{* *} \\
(-2.47)\end{array}$ & $\begin{array}{l}-1.745 \\
(-1.47)\end{array}$ & $\begin{array}{l}-3.020 * * \\
(-2.39)\end{array}$ & $\lg d p$ & $\begin{array}{l}-3.588^{* *} \\
(-4.35)\end{array}$ & $\begin{array}{c}-3.637 * * \\
(-3.75)\end{array}$ & $\begin{array}{l}-4.184 * * \\
(-3.28)\end{array}$ & $\begin{array}{l}-3.652 * * \\
(-3.01)\end{array}$ & $\lg d p$ & $\begin{array}{c}-1.796 * * \\
(-3.21)\end{array}$ & $\begin{array}{l}-1.855^{* *} \\
(-3.26)\end{array}$ & $\begin{array}{c}-1.360^{* *} \\
(-8.85)\end{array}$ & $\begin{array}{l}-1.453 * * \\
(-8.73)\end{array}$ \\
\hline Sub-Saharan & $\begin{array}{l}-2.899 * * \\
(-3.96)\end{array}$ & $\begin{array}{l}-5.537 * * \\
(-3.93)\end{array}$ & $\begin{array}{l}-5.237^{* *} \\
(-4.18)\end{array}$ & $\begin{array}{l}-6.668 * * \\
(-3.58)\end{array}$ & Sub-Saharan & $\begin{array}{l}-2.957 * * \\
(-2.58)\end{array}$ & $\begin{array}{c}-6.171 * * \\
(-4.38)\end{array}$ & $\begin{array}{l}-5.876 * * \\
(-4.54)\end{array}$ & $\begin{array}{l}-5.315^{* *} \\
(-3.84)\end{array}$ & lpop & $\begin{array}{c}-1.044 * * \\
(-5.93)\end{array}$ & $\begin{array}{l}-0.970 * * \\
(-4.42)\end{array}$ & $\begin{array}{c}-0.373^{* *} \\
(-6.41)\end{array}$ & $\begin{array}{l}-0.429 * * \\
(-6.69)\end{array}$ \\
\hline East Asia & $\begin{array}{l}-0.016 \\
(-0.01)\end{array}$ & $\begin{array}{l}-3.611 \\
(-1.37)\end{array}$ & $\begin{array}{l}2.047 \\
(1.78)\end{array}$ & $\begin{array}{l}1.255 \\
(0.98)\end{array}$ & East Asia & $\begin{array}{l}-5.972 * * \\
(-4.21)\end{array}$ & $\begin{array}{c}-6.171 * * \\
(-4.38)\end{array}$ & $\begin{array}{l}-3.774 * * \\
(-3.01)\end{array}$ & $\begin{array}{l}-3.414 * * \\
(-2.72)\end{array}$ & Franc Zone & $\begin{array}{l}0.444 \\
(0.51)\end{array}$ & $\begin{array}{l}0.544 \\
(0.61)\end{array}$ & $\begin{array}{l}0.206 \\
(1.16)\end{array}$ & $\begin{array}{l}0.177 \\
(0.99)\end{array}$ \\
\hline assassinations & - & $\begin{array}{l}4.254 \\
(1.07)\end{array}$ & - & $\begin{array}{l}1.884 \\
(0.65)\end{array}$ & assassinations & $\begin{array}{l}8.827 * * \\
(3.77)\end{array}$ & $\begin{array}{c}8.820 * * \\
(3.72)\end{array}$ & $\begin{array}{l}5.584^{*} \\
(1.86)\end{array}$ & $\begin{array}{l}4.885^{* *} \\
(1.59)\end{array}$ & Egypt & - & - & $\begin{array}{l}0.848^{* *} \\
(2.20)\end{array}$ & $\begin{array}{l}0.957 * * \\
(2.43)\end{array}$ \\
\hline \multirow[t]{2}{*}{ ethnic } & - & $\begin{array}{l}0.815 \\
(1.45)\end{array}$ & - & $\begin{array}{l}0.153 \\
(0.43)\end{array}$ & ethnic & $\begin{array}{l}1.582 * * \\
(4.50)\end{array}$ & $\begin{array}{c}1.569 * * \\
(4.00)\end{array}$ & $\begin{array}{l}0.749 * * \\
(2.12)\end{array}$ & $\begin{array}{l}0.872 * * \\
(2.46)\end{array}$ & ldonor & $\begin{array}{l}0.075 \\
(0.04)\end{array}$ & $\begin{array}{l}0.151 \\
(0.08)\end{array}$ & $\begin{array}{l}1.766^{* *} \\
(3.75)\end{array}$ & $\begin{array}{l}1.915^{* *} \\
(4.02)\end{array}$ \\
\hline & & & & & $\begin{array}{l}\text { Central } \\
\text { America }\end{array}$ & $\begin{array}{l}3.601 * * \\
(2.82)\end{array}$ & $\begin{array}{c}3.236^{* *} \\
(2.63)\end{array}$ & $\begin{array}{l}2.211^{*} \\
(1.92)\end{array}$ & $\begin{array}{l}2.675^{* *} \\
(2.29)\end{array}$ & $\begin{array}{l}\text { Central } \\
\text { America }\end{array}$ & $\begin{array}{c}-1.425^{*} \\
(-1.79)\end{array}$ & $\begin{array}{l}-1.227 \\
(-1.45)\end{array}$ & $\begin{array}{l}-0.116 \\
(-0.50)\end{array}$ & $\begin{array}{l}-0.056 \\
(-0.24)\end{array}$ \\
\hline openness & - & $\begin{array}{l}0.014 \\
(1.03)\end{array}$ & - & $\begin{array}{l}0.030 * * \\
(2.91)\end{array}$ & openness & - & $\begin{array}{l}0.005 \\
(0.41)\end{array}$ & - & $\begin{array}{l}-0.020 \\
(-1.47)\end{array}$ & openness & - & $\begin{array}{l}0.004 \\
(0.53)\end{array}$ & - & $\begin{array}{l}-0.005^{* *} \\
(-2.09)\end{array}$ \\
\hline $\begin{array}{l}\text { government } \\
\text { size }\end{array}$ & $\begin{array}{l}-0.085^{* *} \\
(-2.03)\end{array}$ & $\begin{array}{c}-0.082 * \\
(-1.66)\end{array}$ & $\begin{array}{l}-0.114 \\
(-1.43)\end{array}$ & $\begin{array}{l}-0.197 * * \\
(-2.14)\end{array}$ & $\begin{array}{l}\text { government } \\
\text { size }\end{array}$ & $\begin{array}{l}0.057 \\
(1.11)\end{array}$ & $\begin{array}{c}0.0454 \\
(0.89)\end{array}$ & $\begin{array}{l}-0.083 \\
(-0.80)\end{array}$ & $\begin{array}{l}-0.039 \\
(-0.35)\end{array}$ & & & & & \\
\hline aid & $\begin{array}{c}0.324 * \\
(1.76)\end{array}$ & $\begin{array}{l}0.447 * * \\
(1.54)\end{array}$ & $\begin{array}{l}1.283 * \\
(1.85)\end{array}$ & $\begin{array}{l}1.038 \\
(1.24)\end{array}$ & aid & $\begin{array}{l}0.571 * * \\
(2.47)\end{array}$ & $\begin{array}{l}0.490 * \\
(1.76)\end{array}$ & $\begin{array}{l}1.301 \\
(1.30)\end{array}$ & $\begin{array}{l}1.513 \\
(1.61)\end{array}$ & & & & & \\
\hline rent-seeking & $\begin{array}{l}-0.266 * * \\
(-2.25)\end{array}$ & $\begin{array}{l}-0.762 * * \\
(-2.31)\end{array}$ & $\begin{array}{l}-0.321 * * \\
(-2.24)\end{array}$ & $\begin{array}{l}-0.460 * \\
(-1.93)\end{array}$ & & & & & & rent-seeking & $\begin{array}{l}-0.038 \\
(-0.43)\end{array}$ & $\begin{array}{l}-0.050 \\
(-0.55)\end{array}$ & $\begin{array}{l}-0.012 \\
(-0.44)\end{array}$ & $\begin{array}{l}-0.027 \\
(-0.93)\end{array}$ \\
\hline
\end{tabular}

Notes: t-ratios are in parentheses. An asterisk denotes significance at the $10 \%$ level and two asterisks at the $5 \%$ level. 


\section{CESifo Working Paper Series}

(for full list see www.cesifo.de)

1091 Herwig Immervoll and Cathal O’Donoghue, Employment Transitions in 13 European Countries. Levels, Distributions and Determining Factors of Net Replacement Rates, November 2003

1092 Nabil I. Al-Najjar, Luca Anderlini \& Leonardo Felli, Undescribable Events, November 2003

1093 Jakob de Haan, Helge Berger and David-Jan Jansen, The End of the Stability and Growth Pact?, December 2003

1094 Christian Keuschnigg and Soren Bo Nielsen, Taxes and Venture Capital Support, December 2003

1095 Josse Delfgaauw and Robert Dur, From Public Monopsony to Competitive Market. More Efficiency but Higher Prices, December 2003

1096 Clemens Fuest and Thomas Hemmelgarn, Corporate Tax Policy, Foreign Firm Ownership and Thin Capitalization, December 2003

1097 Laszlo Goerke, Tax Progressivity and Tax Evasion, December 2003

1098 Luis H. B. Braido, Insurance and Incentives in Sharecropping, December 2003

1099 Josse Delfgaauw and Robert Dur, Signaling and Screening of Workers' Motivation, December 2003

1100 Ilko Naaborg, Bert Scholtens, Jakob de Haan, Hanneke Bol and Ralph de Haas, How Important are Foreign Banks in the Financial Development of European Transition Countries?, December 2003

1101 Lawrence M. Kahn, Sports League Expansion and Economic Efficiency: Monopoly Can Enhance Consumer Welfare, December 2003

1102 Laszlo Goerke and Wolfgang Eggert, Fiscal Policy, Economic Integration and Unemployment, December 2003

1103 Nzinga Broussard, Ralph Chami and Gregory D. Hess, (Why) Do Self-Employed Parents Have More Children?, December 2003

1104 Christian Schultz, Information, Polarization and Delegation in Democracy, December 2003

1105 Daniel Haile, Abdolkarim Sadrieh and Harrie A. A. Verbon, Self-Serving Dictators and Economic Growth, December 2003 
1106 Panu Poutvaara and Tuomas Takalo, Candidate Quality, December 2003

1107 Peter Friedrich, Joanna Gwiazda and Chang Woon Nam, Development of Local Public Finance in Europe, December 2003

1108 Silke Uebelmesser, Harmonisation of Old-Age Security Within the European Union, December 2003

1109 Stephen Nickell, Employment and Taxes, December 2003

1110 Stephan Sauer and Jan-Egbert Sturm, Using Taylor Rules to Understand ECB Monetary Policy, December 2003

1111 Sascha O. Becker and Mathias Hoffmann, Intra-and International Risk-Sharing in the Short Run and the Long Run, December 2003

1112 George W. Evans and Seppo Honkapohja, The E-Correspondence Principle, January 2004

1113 Volker Nitsch, Have a Break, Have a ... National Currency: When Do Monetary Unions Fall Apart?, January 2004

1114 Panu Poutvaara, Educating Europe, January 2004

1115 Torsten Persson, Gerard Roland, and Guido Tabellini, How Do Electoral Rules Shape Party Structures, Government Coalitions, and Economic Policies? January 2004

1116 Florian Baumann, Volker Meier, and Martin Werding, Transferable Ageing Provisions in Individual Health Insurance Contracts, January 2004

1117 Gianmarco I.P. Ottaviano and Giovanni Peri, The Economic Value of Cultural Diversity: Evidence from US Cities, January 2004

1118 Thorvaldur Gylfason, Monetary and Fiscal Management, Finance, and Growth, January 2004

1119 Hans Degryse and Steven Ongena, The Impact of Competition on Bank Orientation and Specialization, January 2004

1120 Piotr Wdowinski, Determinants of Country Beta Risk in Poland, January 2004

1121 Margarita Katsimi and Thomas Moutos, Inequality and Redistribution via the Public Provision of Private Goods, January 2004

1122 Martin Peitz and Patrick Waelbroeck, The Effect of Internet Piracy on CD Sales: CrossSection Evidence, January 2004

1123 Ansgar Belke and Friedrich Schneider, Privatization in Austria: Some Theoretical Reasons and First Results About the Privatization Proceeds, January 2004 
1124 Chang Woon Nam and Doina Maria Radulescu, Does Debt Maturity Matter for Investment Decisions?, February 2004

1125 Tomer Blumkin and Efraim Sadka, Minimum Wage with Optimal Income Taxation, February 2004

1126 David Parker, The UK's Privatisation Experiment: The Passage of Time Permits a Sober Assessment, February 2004

1127 Henrik Christoffersen and Martin Paldam, Privatization in Denmark, 1980-2002, February 2004

1128 Gregory S. Amacher, Erkki Koskela and Markku Ollikainen, Deforestation, Production Intensity and Land Use under Insecure Property Rights, February 2004

1129 Yin-Wong Cheung, Javier Gardeazabal, and Jesús Vázquez, Exchange Rate Dynamics: Where is the Saddle Path?, February 2004

1130 Alberto Alesina and Guido Tabellini, Bureaucrats or Politicians?, February 2004

1131 Gregory S. Amacher, Erkki Koskela, and Markku Ollikainen, Socially Optimal Royalty Design and Illegal Logging under Alternative Penalty Schemes, February 2004

1132 David M. Newbery, Privatising Network Industries, February 2004

1133 Charles Yuji Horioka, The Stagnation of Household Consumption in Japan, February 2004

1134 Eiji Fujii, Exchange Rate Pass-Through in the Deflationary Japan: How Effective is the Yen's Depreciation for Fighting Deflation?, February 2004

1135 Mark M. Spiegel and Nobuyoshi Yamori, Determinants of Voluntary Bank Disclosure: Evidence from Japanese Shinkin Banks, Febrary 2004

1136 Robert Dekle and Kenneth Kletzer, Deposit Insurance, Regulatory Forbearance and Economic Growth: Implications for the Japanese Banking Crisis, February 2004

1137 Takatoshi Ito and Kimie Harada, Bank Fragility in Japan, 1995-2003, February 2004

1138 Kunio Okina and Shigenori Shiratsuka, Policy Duration Effect under Zero Interest Rates: An Application of Wavelet Analysis, February 2004

1139 Francine D. Blau and Lawrence M. Kahn, Do Cognitive Test Scores Explain Higher U.S. Wage Inequality?, February 2004

1140 Michael Rauscher, Economic Growth and Tax-Competing Leviathans, February 2004

1141 Ernst Fehr and Jean-Robert Tyran, Money Illusion and Coordination Failure, February 2004 
1142 Ingo Vogelsang, Network Utilities in the U.S. - Sector Reforms without Privatization, March 2004

1143 Marc-Andreas Muendler, Estimating Production Functions When Productivity Change is Endogenous, March 2004

1144 Sascha O. Becker, Samuel Bentolila, Ana Fernandes, and Andrea Ichino, Job Insecurity and Children's Emancipation, March 2004

1145 Pascalis Raimondos-Møller and Alan D. Woodland, Non-Preferential Trading Clubs, March 2004

1146 Robert Fenge and Matthias Wrede, EU Regional Policy: Vertical Fiscal Externalities and Matching Grants, March 2004

1147 Chi-Yung Ng and John Whalley, Geographical Extension of Free Trade Zones as Trade Liberalization: A Numerical Simulation Approach, March 2004

1148 Marc-Andreas Muendler, Trade, Technology, and Productivity: A Study of Brazilian Manufacturers, 1986-1998, March 2004

1149 Eugene Beaulieu, Vivek H. Dehejia, and Hazrat-Omar Zakhilwal, International Trade, Labour Turnover, and the Wage Premium: Testing the Bhagwati-Dehejia Hypothesis for Canada, March 2004

1150 Giorgio Brunello and Francesca Gambarotto, Agglomeration Effects on EmployerProvided Training: Evidence from the UK, March 2004

1151 S. Brock Blomberg, Gregory D. Hess, and Athanasios Orphanides, The Macroeconomic Consequences of Terrorism, March 2004

1152 Bodo Sturm and Joachim Weimann, Unilateral Emissions Abatement: An Experiment, March 2004

1153 Wolfgang Ochel, Welfare-to-Work Experiences with Specific Work-First Programmes in Selected Countries, March 2004

1154 Jan K. Brueckner and Eric Pels, European Airline Mergers, Alliance Consolidation, and Consumer Welfare, March 2004

1155 Aaron Tornell, Frank Westermann, and Lorenza Martínez, NAFTA and Mexico's Economic Performance, March 2004

1156 George Economides, Sarantis Kalyvitis, and Apostolis Philippopoulos, Do Foreign Aid Transfers Distort Incentives and Hurt Growth? Theory and Evidence from 75 Aidrecipient Countries, March 2004 